\title{
TWO-DIMENSIONAL ANALYSIS OF THE INFLUENCE OF STRATEGIC NETWORKING ON ENTREPRENEURIAL ORIENTATION AND BUSINESS PERFORMANCE AMONG SMES
}

\author{
Bojan Morić Milovanović, Dinko Primorac, Goran Kozina
}

Original scientific paper

Strategic networking $(S N)$ is the process through which firms leverage specialization, efficiently allocate transformational resources and optimize support through information sharing. The purpose of this paper is to examine the influence of strategic networking $(S N)$ on entrepreneurial orientation and firm performance of Croatian SMEs, one of a dozen small, open and still-transitioning European economies. Financial and non-financial indicators were used in order to more precisely clarify the multidimensional aspect of the $S N$-EO-performance relationships. The external environment was assessed in terms of turbulence, hostility and dynamism, where its direct effect on $S N$ and $E O$ was tested. Research results indicate that defined structural model has a satisfactory fit level to empirical data and that structural coefficients lead to the acceptance of the research hypotheses. More importantly, the results yield some significantly new elements necessary for understanding the role of $S N$ for the $E O$ and performance of SMEs in a developing economy.

Keywords: business performance; entrepreneurial orientation; SMEs; strategic networking

\section{Dvodimenzijska analiza utjecaja strateškog umrežavanja na poduzetničku orijentaciju i uspješnost poslovanja među malim i} srednjim poduzećima

Strateško umrežavanje predstavlja proces pomoću kojeg poduzeća ostvaruju povećanu specijalizaciju, efikasnije alociraju transformacijske resurse te optimiziraju međusobnu potporu putem razmjene informacija, intenzivne suradnje i poboljšanja reputacije. Svrha ovog članka je ispitati utjecaj strateškog umrežavanja na poduzetničku orijentaciju i uspješnost poslovanja hrvatskih malih i srednjih poduzeća, u kontekstu jedne od desetak drugih malih, otvorenih, tranzicijskih europskih ekonomija. U istraživanju su korišteni financijski i nefinancijski pokazatelji uspješnosti kako bi se preciznije ustanovio višedimenzijski odnos između strateškog umrežavanja, poduzetničke orijentacije i poslovne uspješnosti. Okolina je mjerena pomoću koncepata turbulentnosti, suparništva i dinamičnosti pri čemu je testiran izravan utjecaj okoline na strateško umrežavanje i poduzetničku orijentaciju. Rezultati istraživanja ukazuju da definirani strukturni model posjeduje zadovoljavajuću razinu prikladnosti empirijskim podacima, te ujedno strukturni koeficijenti potvrđuju postavljene istraživačke hipoteze. Također, rezultati istraživanja doprinose jasnijem razumijevanju uloge strateškog umrežavanja na poduzetničku orijentaciju i uspješnost poslovanja malih i srednjih poduzeća koja posluju u tranzicijskoj ekonomiji.

Ključne riječi: mala i srednja poduzeća; poduzetnička orijentacija; strateško umrežavanje; uspješnost poslovanja

\section{Introduction}

Small and medium sized enterprises play an important role in the evolution of a majority of world economies. This notion applies particularly in the context of several Central European economies that resulted from political disruption and geographical fragmentation during the post-cold war era since the 1980s. Despite macroeconomic turbulence, transition and transformation of the national economies, the small business sectors in such economies continue to represent a perceived resilient variable and deserve attention for their disproportionate contributions to stabilizing economic evolution and reintegration. As one such particular example we investigate here the significance of small business firms' strategic posture on their strategic networking $(S N)$ activities and entrepreneurial orientation (EO), consequently resulting in significant economic performance in the context of the Croatian economy.

A number of studies have attempted to show that firms with more $S N$ and $E O$ perform 'better' than those with lower levels of $S N$ and $E O$. However, the empirical validity as well as the reliability of the findings remains elusive and inconclusive. This prompts the author to further refine if, and to investigate to what extent, economic performance is a result of the complex relationship between $S N, E O$ and the firm's strategic posture.

One strain in the literature has confirmed that the relationship between $S N, E O$ and economic performance is contingent on the industry in which the company operates, depending itself again on the various internal and external factors (Lumpkin and Dess [35]; Gulati, Nohria and Zaheer [22]). This paper attempts to contribute to this existing literature by analyzing the link between $S N, E O$ and economic performance of small and medium firms. Furthermore, it continues in the tradition of this existing strain in the literature that has established that $S N$ and $E O$ can be investigated as a one-dimensional but also multidimensional construct. We also acknowledge and replicate the research that has tested the resulting economic performance with regards to financial and non-financial aspects of the firms' economic and business performance.

The data for this research were obtained from a sample of 252 SMEs using structural equation modeling (SEM) and multiple linear regression analysis to test the relationships between $S N$ and $E O$ variables and business performance on one side, and $S N$ and $E O$ variables and external environment $(E E)$ on the other side. The analysis indicates that $S N$ and $E O$ positively influence small business performance, while the EE has a positive impact on the firm's $S N$ and $E O$, as well.

\section{Literature review and hypotheses}

Changes caused by globalization and development of new technologies directly influenced the transformation of organizational structures by making them thinner, more flexible and decentralized. Answer to these changes had 
been found in the form of networks as a flexible, dynamic and effective form of organizational structure. For this reason, all economic sectors are characterized by a dramatic increase in network activity and various forms inter-organizational connectivity (Borgatti and Foster [9]; Anderson, Dodd and Jack [3]). Network relations are based on trust and long-term commitment, therefore represent a higher and more developed form than a traditional relationship between a buyer and a seller (Cook et al. [12]). Networks can be defined as a structure of long-term relationships between companies or between company's organizational units (Borgatti and Halgin [8]). From this definition it can be concluded that networks could be formed within companies, between companies and as their combination. Relationships between companies can be of unilateral or bilateral character by which products, services, resources and equity are exchanged, control activities are conducted, and by which various communication and cooperation activities are conducted. Companies that commit themselves to a long term network relationship implicitly suggest that they can achieve greater strategic benefit from cooperation than by competition (Human and Provan [25]).

Strategic networks can be defined as intentionally formed groups of companies that are geographically close, operate in the same industry and exchange inputs and outputs, in order to achieve certain business activities (Human and Provan [25]). Since companies have established long-term relationships based on trust, they are able to exchange key competencies and resources to achieve those goals that individually would not be able to. Therefore, the purpose of SN is the formation of a joint activity among the network members where members at the same time contribute inputs to the network and realize benefits by using the other member's outputs (Gulati, Nohria and Zaheer [22]). Mutual cooperation and exchange represent the basis for value creation and competitive advantage generation in SN (Human and Provan [25]). Various authors have defined SN as a multidimensional construct through its antecedents: a) commitment, b) trust, c) reputation, d) communication and e) cooperation (Chang and Harwood [11]; Anderson and Narus [4])

$E O$ is a concept that is taking place at the organizational level and is closely linked with strategic management and decision making processes (Covin and Slevin [13]; Naman and Slevin [41]). EO is defined as the firm's propensity to act autonomously and innovatively, to take risks and to take proactive initiatives regarding potential market opportunities (Lumpkin and Dess [34]). $E O$ is a process that is related to methods, practices and decision-making styles of managers (Lumpkin and Dess [34]). According to Lumpkin and Dess [34] EO is an integral part of the concept of strategic choice, and refers to the intentions and actions of key decision makers in a dynamic process. $E O$ promotes entrepreneurial initiatives throughout all organizational levels with respect to the formulation and implementation of a business strategy (Birkinshaw [7].) Lumpkin and Dess [34] consider that if the company wants to become truly entrepreneurial, it needs to aspire to achieve an efficient combination of the following five dimensions: (a) innovativeness, (b) proactiveness, (c) risk taking, (d) autonomy and (c) competitive aggressiveness.

The literature does not offer a consensus regarding whether dimensions of $E O$ work together or not (Kreiser et al. [28]). Some researchers believe that a company can act in an entrepreneurial way only if it uses high levels of all five dimensions of $E O$ (Miller, [38]). On the other hand, some believe that $E O$ should be viewed as a unidimensional construct based on 'strategic orientation' (Covin and Slevin [14]) as the sole dimension.

It is possible that certain companies manifest a relatively high level of one dimension or high levels of several dimensions, while other dimensions of $E O$ have relatively low values at the same time (Lyon, Lumpkin and Dess [36]). This sort of discrepancy may arise from the fact that entrepreneurs can achieve highly positive business results without having to be risk-inclined, innovative or proactive. Entrepreneurs can simply use strategies which focus on imitation rather than innovation. Therefore, in order to better understand a firm's entrepreneurial activity and entrepreneurial behavior in different contexts, many researchers suggest that $E O$ should be seen as a multidimensional construct which, in turn, would allow the examination of the impact of individual dimensions of $E O$ on business performance (Kreiser et al. [28], Lumpkin and Dess [35]).

\subsection{Strategic networking and performance}

Networking theory states that the firm's competitive advantage resides on collaborative business relationships (Gulati, Nohria and Zaheer [22]), and that entrepreneurs through networking activities are able to gain the access to those resources that they do not control, thus affecting their business performance (Zhao and Aram [55]). By forming a business network companies can reduce risk levels, production costs, increase flexibility, efficiency and knowledge capacities, all of which ultimately lead to higher performance levels (Lin and Zhang [32]). Through business networks companies are able to better predict, prevent and absorb uncertainties that affect their operations and are able to jointly access previously inaccessible markets (Saleh and Ndubisi [44]).

Successful companies more often use expert advice (Street and Cameron [47]) and increasingly rely on information provided by their accountants in comparison to less successful companies (Robson and Bennett [42]). Moreover, the lack of contacts with business professionals represents an obstacle to the further business expansion (Larsson et al. [30]). In their study, Donckels and Lambrecht [17]) found that the development of networks has a positive effect on business growth, Saleh and Ndubisi [44] determined that it leads to significant revenue growth and customer base expenditure, while Lerner, Brush and Hisrich [31] affirmed that network participation significantly contributes to the increased profitability. We thus propose to test the following hypotheses and their corollaries:

H1: $S N$ has a positive effect on small business performance.

H1a: Commitment has a positive effect on small business performance. 
H1b: Trust has a positive effect on small business performance.

H1c: Reputation has a positive effect on small business performance.

H1d: Communication has a positive effect on small business performance.

H1e: Cooperation has a positive effect on small business performance.

\subsection{Strategic networking and entrepreneurial orientation}

Companies in strategic network share inputs and outputs in order to achieve certain business activities (Human and Provan [25]). Since companies are close to each other, they are able by exchanging key competencies and resources to achieve certain goals that individually would not have been able to. Therefore, the purpose of strategic network is the formation of a platform for the realization of joint activities among member-firms. Evolvent of entrepreneurial orientation among network members arises as a consequence of their open communication, resource exchange, long-term cooperation and higher proclivity towards risk (Kusumawardhani et al. [29]; Awang et al. [6]). Moreover, higher levels of trust, communication and cooperation among companies lead to a greater exchange of sensitive information and resources that each company by itself does not possess, whereby companies become more knowledge abundant, which in turn leads to the creation of innovations and to the proactive approach towards development of new products, services or entirely new markets (Human and Provan [25]); Street and Cameron 47]). We thus propose to test the following hypotheses:

$\mathrm{H} 2: \mathrm{SN}$ has a positive effect on $E O$.

$\mathrm{H} 2 \mathrm{a}$ : Commitment has a positive effect on $E O$.

$\mathrm{H} 2 \mathrm{~b}$ : Trust has a positive effect on $E O$.

$\mathrm{H} 2 \mathrm{c}$ : Reputation has a positive effect on $E O$.

$\mathrm{H} 2 \mathrm{~d}$ : Communication has a positive effect on $E O$.

$\mathrm{H} 2 \mathrm{e}$ : Cooperation has a positive effect on $E O$.

\subsection{Entrepreneurial orientation and performance}

Several papers have attempted to explain a firm's business performance through $E O$. Dess et al. [16] have explored the nature of entrepreneurial strategy-making process and its relationship to strategy, environment and performance. Covin and Slevin [13] had developed a model which links a firm's $E O$ to its performance. These authors found that $E O$ has a positive impact on business performance. Miller and Bromiley [40] found that $E O$ has an impact on the overall business performance indicators such as return on assets, equity and sales. Zahra [52] found a positive relationship between $E O$ and a company's profitability and growth. Wiklund [49] confirmed the existence of a positive relationship between $E O$ and performance. Many other studies also seem to confirm the finding of a positive effect of $E O$ on firms' business performance (Zahra and Covin [53]; Kraus et al. [27]). Based on this critical mass of the salient literature we propose that there is a general positive connection between EO and various indicators of business performance (Wiklund and Shepherd [50]; Zahra and
Covin [53]). Consequently, we propose to further test the following hypotheses:

H3: $E O$ has a positive effect on small business performance.

H3a: Innovativeness has a positive effect on small business performance.

$\mathrm{H} 3 \mathrm{~b}$ : Proactiveness has a positive effect on small business performance.

H3c: Risk-taking has a positive effect on small business performance.

H3d: Autonomy has a positive effect on small business performance.

H3e: Competitive aggressiveness has a positive effect on small business performance.

\subsection{External environment and strategic networking}

Modern entrepreneurs are faced with ever dynamic, complex and unpredictable business environment in which technology, globalization, lack of resources, frequent fluctuations in business cycles, changes in social values, competition, customers, suppliers, and many other various dynamic forces which affect overall business performance (Ward and Lewandowska [48]; Asch and Salaman [5]). Intensity and complexity of the current environment changes are putting pressure on companies to look for new possibilities of conducting a business with the purpose for creating new added value (Stopford [46]). Therefore, turbulent, dynamic and hostile environment has a significant impact on networking activities of small and medium sized enterprises since in this kind of environment firms are compelled to share information, resources, knowledge, and to constantly seek new sales and distribution channels, suppliers and all other stakeholders that have an impact on their business performance. To that end, we propose to test the following hypotheses:

H4: External environment has a positive effect on $S N$.

H4a: Turbulence has a positive effect on $S N$.

H4b: Hostility has a positive effect on $S N$.

$\mathrm{H} 4 \mathrm{c}$ : Dynamism has a positive effect on $S N$.

\subsection{External environment and entrepreneurial orientation}

External environment can be defined in numerous ways, but most define it using the following aspects: turbulence (Roger [43]; Naman and Slevin [41]), hostility and dynamism (Yeoh [51]). Environmental turbulence as a concept combines unpredictability, expansion and fluctuations in the environment (Roger [43]). Environmental hostility is sometimes referred to as a high-velocity environment which is characterized by the intense competition via price, product and technology, additionally as a lack of resources (e.g. lack of raw materials, human resources, etc.), serious regulatory restrictions, the relative lack of exploitable opportunities, and negative demographic trends (Miller and Friesen [39]). Dynamism represents the perceived instability and the continuity of changes within the firm's environment. It can be expressed as an extent of predictability of a change in the environment, as the level of uncertainty in the environment, and can be manifested as the variance in the 
rate of market and industry change (Boyd, Dess and Rasheed [10]).

Impact of external environment on $E O$ has been observed by many authors as an important determinant of $E O$ at both individual and organizational levels (Desarbo et al. [9]; Zahra and Covin [54]; Dess et al. [16]), while it has a moderating effect on the various business strategies (Greenley and Foxall [21]). Therefore, in today's uncertain and turbulent environment companies are forced to behave in an entrepreneurial way in order to try to survive in the market. Additionally, rapid changes in technology and shorter product cycles are forcing companies to be innovative in order to develop new ideas, products and processes, and to willingly take calculated risks in order to cope with market changes. Moreover, increasing competition, both domestic and foreign emphasizes the need for a more proactive market approach. We examine the above via the following hypotheses: $E O$.

H4: External environment has a positive effect on

H4a: Turbulence has a positive effect on $E O$.

$\mathrm{H} 4 \mathrm{~b}$ : Hostility has a positive effect on $E O$.

$\mathrm{H} 4 \mathrm{c}$ : Dynamism has a positive effect on $E O$.

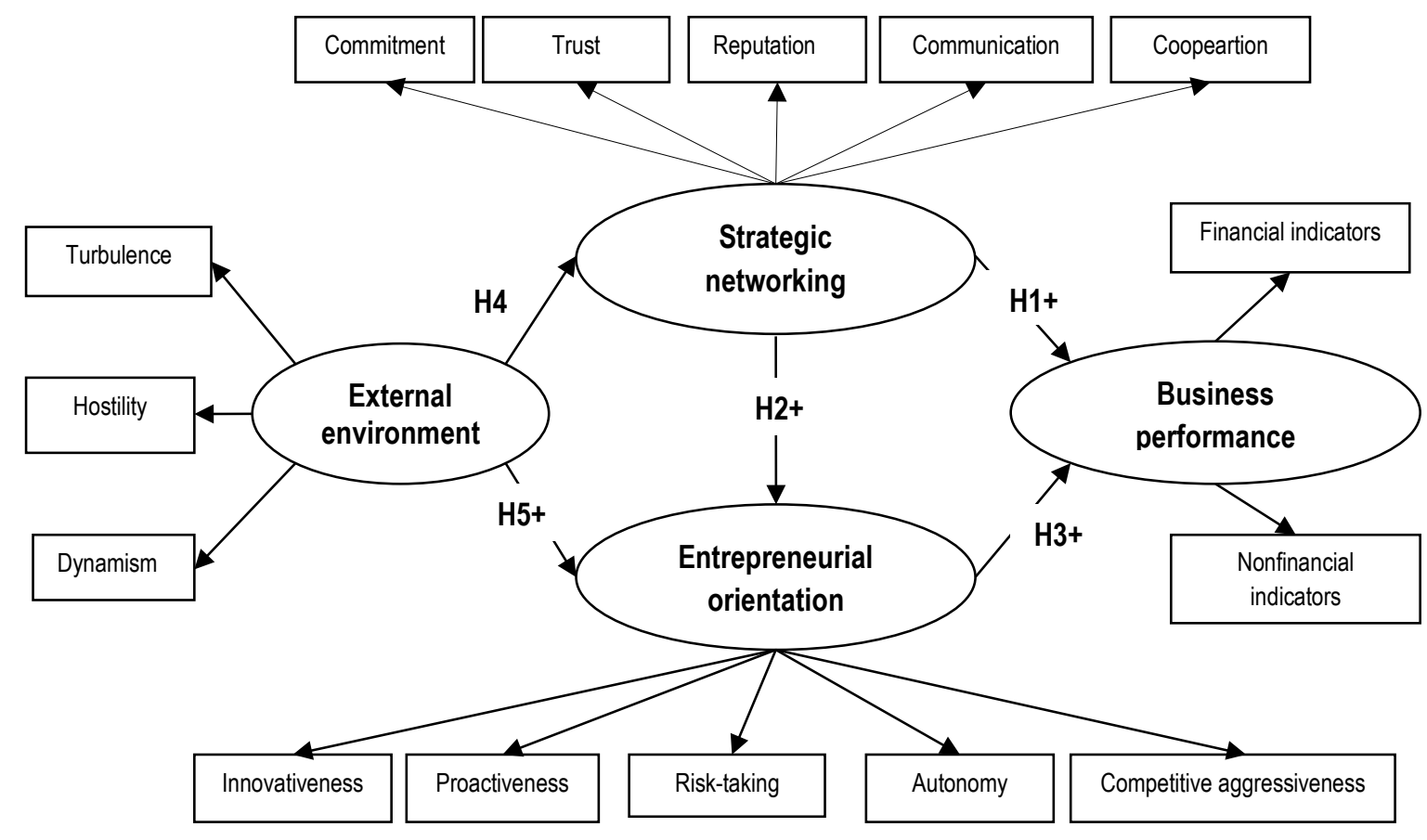

Figure 1 Conceptual model and hypotheses

\section{Research method}

\subsection{Sample}

The sampling frame was taken from the database of the Croatian Chamber of Economy, which includes all incorporated Croatian companies. A random sample of independent firms from the service sector was taken. One half of the companies in the sample had between 1 and 49 employees and the other half had between 50 and 249 employees; this corresponds to the European Union's definition of small and medium sized enterprises respectively. A total of 2223 small and medium sized business owners/managers from the sampling frame were contacted in June and July 2011 out of which 252 responded to a mail questionnaire (resulting in a response rate of $11,4 \%$ ). Regarding the business size of the respondents, $25 \%(n=63)$ were micro firms, $41 \%(n=$ $103)$ were small firms and $34 \%(n=86)$ were medium sized firms.

\subsection{Variables and measures}

Strategic networking was conceptualized using five variables: commitment, trust, reputation, communication and cooperation. Each of these variables was measured with three questions using a seven point Likert scale. Commitment was measured using Allen and Meyer [2] scale, trust using Garbarino and Johnson [20] scale, reputation using Hansen, Samuelsen and Silseth [24] scale, communication using Sivadas and Dwyer [45] scale, while cooperation was measured by Eriksson and Pesamaa [19] scale.

Entrepreneurial orientation was operationalized using five variables: innovativeness, proactiveness, risk taking, autonomy and competitive aggressiveness. Each of these variables was measured with three questions using a seven point Likert scale. Innovativeness, proactiveness and risk taking were measured using Covin and Slevin's [14] scale, while autonomy was measured by Lumpkin, Cogliser and Schneider's [33] scale and competitive aggressiveness by the one provided by Aktan and Bulut [1].

The external environment was operationalized using three variables (turbulence, hostility and dynamism) by Naman and Slevin [41] each of these variables was measured with three questions using a seven point Likert scale.

Business performance was operationalized accordingly by Gupta and Govindarajan [23] where the respondents were asked to rate the extent to which stated 
financial and non-financial indicators are important for their business, and subsequently, to assess the extent of satisfaction with the achieved performance of these indicators. For this purpose three financial and three nonfinancial indicators were used; each of the indicators was measured with three questions using a seven point Likert scale.

\subsection{Analysis}

Structural equation modeling was used to test the relationships between main (latent) constructs in the proposed model, while a multiple linear regression analysis was used to test the relationships between business performance and second-order variables that operationalize $S N, E O$ and $E E$.

\section{Results}

To test the main hypotheses as displayed in Fig. 1, data was analyzed using structural equation modeling. The overall model demonstrated acceptable fit since all of the goodness of fit measures met recommended cutoff values $\left(\chi^{2}=177,534 ; \chi^{2} / \mathrm{ss}=2,165 ; G F I=0,916 ; A G F I=\right.$ 0,$877 ;$ RMSEA $=0,068 ; C F I=0,925 ; I F I=0,927$ and $T L I$ $=0,905)$. Moreover, a very large proportion of the variance of the variable business performance was explained by the model $\left(R^{2}=0,30\right)$. Individual items show good reliability (Cronbach alfa coefficients of all model variables are well above 0,7) and exhibit significant and substantial loadings on their intended constructs indicating good convergent validity (Tab. 1) and good discriminatory validity $\left(A V E>r^{2}\right.$; Tab. 2). Structural equation modeling enabled an examination of all relationships simultaneously instead of separately, as would have been true with path analysis.

Table 1 AVE values of model variables

\begin{tabular}{|l|c|}
\hline \multicolumn{1}{|c|}{ Variable } & $A V E(>0,5)$ \\
\hline External environment $(E E)$ & 0,65 \\
\hline Entrepreneurial orientation $(E O)$ & 0,66 \\
\hline Strategic networking $(S N)$ & 0,65 \\
\hline Business performance & 0,83 \\
\hline
\end{tabular}

Table 2 AVE and $\mathrm{r}^{2}$ comparison of model variables

\begin{tabular}{|c|c|c|c|}
\hline Variable & $E E$ & $E O$ & $S N$ \\
\hline \multirow{2}{*}{$E O$} & $0,65>0,0408$ & & \\
& $0,66>0,0408$ & & \\
\hline \multirow{2}{*}{$S N$} & $0,65>0,0069$ & $0,66>0,2228$ & \\
& $0,65>0,0069$ & $0,65>0,2228$ & \\
\hline \multirow{2}{*}{ Performance } & $0,65>0,0001$ & $0,66>0,1354$ & $0,65>0,2088$ \\
& $0,83>0,0001$ & $0,83>0,1354$ & $0,83>0,2088$ \\
\hline
\end{tabular}

Unstandardized coefficients, standardized coefficients, standard errors, critical ratios and $p$-values for the relationships between structure model variables are displayed in Tab. 3. As it is clearly seen from the Tab. 3, $S N$ has a significantly positive influence on business performance $(r=0,18 ; P<0,05)$ and $E O(r=0,60 ; P<$ $0,01), E O$ positively influences business performance $(r=$ $0,41 ; P<0,01)$ while $E E$ has a significantly positive influence on $S N(r=0,13 ; P<0,10)$ and $E O(r=0,19 ; P$ $<0,05)$, as well. Therefore, these findings support Hypothesis 1, 2, 3, 4 and 5.

Table 3 Results of CFA analysis for the structure model

\begin{tabular}{|c|c|c|c|c|c|c|}
\hline \multicolumn{2}{|c|}{ Path description } & \multirow{2}{*}{$\begin{array}{c}\begin{array}{c}\text { Unstandardized } \\
\text { coefficient }\end{array} \\
1,797 \\
\end{array}$} & \multirow{2}{*}{$\frac{S . E .}{0,819}$} & \multirow{2}{*}{$\begin{array}{c}\text { C.R. } \\
2,194\end{array}$} & \multirow{2}{*}{$\begin{array}{c}P \\
0,028\end{array}$} & \multirow{2}{*}{$\begin{array}{c}\begin{array}{c}\text { Standard. } \\
\text { coefficient }\end{array} \\
0,183\end{array}$} \\
\hline Business performance & Strategic networking & & & & & \\
\hline Entrepreneurial orientation & Strategic networking & 0,792 & 0,142 & 5,562 & $* * *$ & 0,603 \\
\hline Business performance & Entrepreneurial orientation & 3,095 & 0,842 & 3,676 & $* * *$ & 0,414 \\
\hline Strategic networking & External environment & 0,098 & 0,059 & 1,647 & 0,100 & 0,139 \\
\hline Entrepreneurial orientation & External environment & 0,180 & 0,071 & 2,556 & 0,011 & 0,195 \\
\hline Dynamism & External environment & 1,000 & & & & 0,648 \\
\hline Hostility & External environment & 0,882 & 0,138 & 6,380 & $* * *$ & 0,621 \\
\hline Turbulence & External environment & 1,106 & 0,174 & 6,371 & $* * *$ & 0,680 \\
\hline Trust & Strategic networking & 1,000 & & & & 0,562 \\
\hline Commitment & Strategic networking & 1,411 & 0,221 & 6,397 & $* * *$ & 0,512 \\
\hline Reputation & Strategic networking & 1,064 & 0,117 & 9,069 & $* * *$ & 0,669 \\
\hline Communication & Strategic networking & 1,679 & 0,206 & 8,161 & $* * *$ & 0,771 \\
\hline Cooperation & Strategic networking & 1,940 & 0,240 & 8,083 & $* * *$ & 0,780 \\
\hline Competitive aggressiveness & Entrepreneurial orientation & 1,000 & & & & 0,550 \\
\hline Autonomy & Entrepreneurial orientation & 0,843 & 0,138 & 6,106 & $* * *$ & 0,484 \\
\hline Risk-taking & Entrepreneurial orientation & 1,095 & 0,126 & 8,685 & $* * *$ & 0,587 \\
\hline Proactiveness & Entrepreneurial orientation & 1,546 & 0,184 & 8,408 & $* * *$ & 0,830 \\
\hline Innovativeness & Entrepreneurial orientation & 1,509 & 0,184 & 8,213 & $* * *$ & 0,777 \\
\hline Financial indicators & Business performance & 1,000 & & & & 0,591 \\
\hline Nonfinancial indicators & Business performance & 1,736 & 0,279 & 6,228 & $* * *$ & 1,080 \\
\hline
\end{tabular}

The beta coefficients, standard errors, $R$ squares and adjusted $R$ squares of the multiple regression analysis are displayed in Tab. 4. The absence of multicollinearity was ensured by centering the means of the interaction variables and by applying multicollinearity diagnosis. Variance inflation factors were well below critical values. From the second-order variables that operationalize $S N$ only commitment $(b=0,10 ; P<0,10)$, reputation $(b=$ 
$0,28 ; P<0,01)$ and cooperation $(b=0,16 ; P<0,05)$ have significantly positive effect on business performance. When looking the effect on $E O$ it can be concluded that reputation $(b=0,24 ; P<0,01)$, communication $(b=0,21$;
$P<0,01)$ and cooperation $(b=0,20 ; P<0,01)$ have a significantly positive effect. Therefore, these findings support Hypothesis 1c, 1d, 2c, 2d and 2e.

Table 4 Results of multiple linear regression analysis $(n=252)$

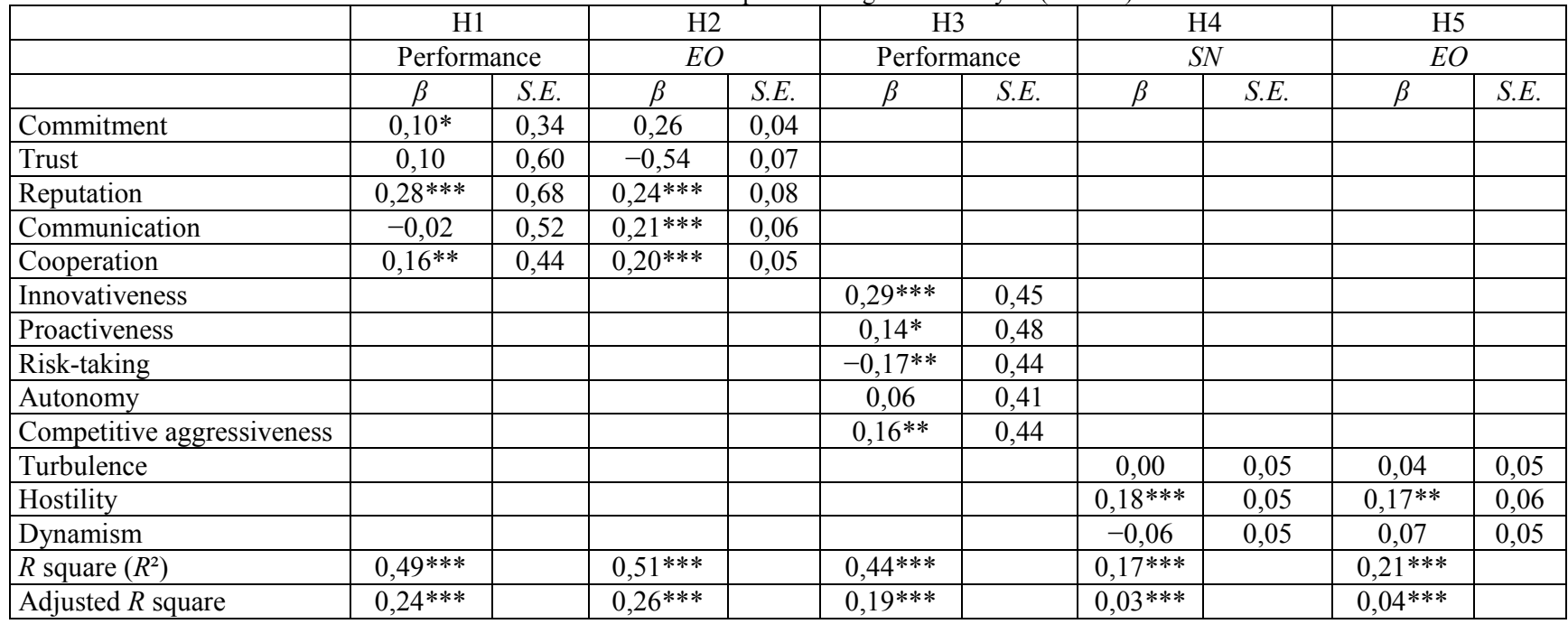

Notes: $* P<0,10 ; * * P<0,05 ; * * * P<0,01$.

From the second-order variables that operationalize $E O$ innovativeness $(b=0,29 ; P<0,01)$, proactiveness $(b$ $=0,14 ; P<0,10)$ and competitive aggressiveness $(b=$ $0,16 ; P<0,05)$ have significantly positive effect on business performance, while risk-taking has a significant influence on business performance $(b=-0,17 ; P<0,05)$ but a negative one. Therefore, these findings support Hypothesis 3a, 3b and 3e. Only hostility as a second-order variable, which operationalizes the external environment, has a significant positive effect on $S N(b=0,18 ; P<0,01)$ and $E O(b=0,17 ; P<0,05)$; this, in turn supports Hypothesis $4 \mathrm{~b}$ and $5 \mathrm{~b}$.

\section{Discussion}

\subsection{Implications for research and management}

Researching the concept of $S N$ and its influence on firm $E O$ and performance in the context of a small transitional country such as Croatia provides a valuable contribution to the existing scientific literature since the majority of previous research was conducted in large and developed countries. Moreover, much of the previous research looked at $S N$ and $E O$ in the context of large companies, while only a small number of studies have focused on observing these concepts among small and medium-sized companies. Literature contribution can be seen in the analysis of the relationship between $S N$ and small business performance in the small transitional economy such as Croatia, adding the effects of $E O$ and $E E$ to the relationship.

The main conclusion to be drawn from our study resides in the recognition that $S N$ and $E O$ positively affect business performance of SMEs in the present context of economically transforming Croatia. This conclusion suggests that small business owners and their management should consider the antecedents of $S \mathrm{~N}$ and $E O$ in defining their business strategies. The research proposes that SME owners and managers can achieve a variety of economic benefits if business strategies that lead to the increase of $S N$ and $E O$ were implemented within the firm. In other words, companies will realize numerous advantages if sophisticated long-term network relationships are established with business partners and if their business activities are characterized by a greater propensity to innovate, increased proactive approaches to market opportunities, more calculated risks, more assertive autonomous behavior and an aggressive stance towards their competitors.

\subsection{Limitations}

The size of the sample represents a certain limitation of the study. Although the sample size and the rate of return seem technically satisfactory and in line with the international publication standards (Klein [26]; Malhotra [37]), future research should be conducted on a larger sample in order to contribute to a more generalizable understanding of the research issues. The study is based on subjective perceptions of firm representatives, comprised of the owners, directors or higher-level management who self-selected in their responses. Directors and managers are personally biased whilst evaluating internal and external organizational environments, while business owners often evaluate their businesses in the context of the emotional connections they have with regard to their family needs, various forms of social relationships and their personal needs and desires.

Limitations can be found in the research design as well. The survey was conducted among small and medium-sized enterprises, where the answers were provided by only one representative of each firm. From a methodological point of view, the research design could be improved if, for example, the study included several representatives from each investigated company. 
This research examined the impact of $S N$ on $E O$ and the firm's business performance observed at one point in time; future research, in turn, may need to be conducted via a longitudinal study. This could provide a clearer insight into the relationship of $S N$ and $E O$ antecedents and various aspects of business performance. Since the research is based solely on subjective measures of observed concepts, i.e. on the individual perceptions of individual firms' representatives, it remains paramount, for purposes of generalizability and comparability to devise more objective metrics.

\section{Conclusion}

Small and medium sized firms represent the most agile, dynamic and innovative sector of any economy. Any investigation of their performance represents an academically worthy effort. Investigating those firms' $S N$ $E O$-business performance relationships in the context of a transitional country such as Croatia in the present study and by observing the unidimensional and multidimensional aspects of the constructs in question, the conducted research may provide an interesting insight into this dynamic process and a preliminary framework for further investigation and generalization for regionalized economies.

Since the said $S N$-EO-business performance relationship differs largely depending on the industry and various internal and external factors, adding the effect of the external environment to the model, observed as uniand as a multi-dimensional construct, makes this research a worthy starting point for future insights into this topic.

When looking at $S N$ and $E O$ as multidimensional constructs, only commitment, reputation, cooperation, innovativeness, proactiveness and competitive aggressiveness have a positive influence on business performance. The external environment as a unidimensional construct positively influences $S N$ and $E O$, while only hostility has a positive influence as a dimension of the external environment. Other dimensions do not show significant influence on $S N$ or $E O$. Regarding the effect of $S N$ on $E O$ it can be concluded that as a unidimensional construct it has a positive influence, while as a multidimensional construct only reputation, communication and cooperation positively influence $E O$.

The findings of this paper are also consistent with previous research in that we suggest that $S N$ (i.e., commitment, trust, reputation, communication and cooperation) and $E O$ (i.e., innovativeness, proactiveness, risk-taking, autonomy and competitive aggressiveness) as unidimensional constructs positively influence business performance of Croatian SMEs. This particular conclusion of the paper may yield the opportunity for a new investigative angle for academics, researchers and management executives among private and public professional bodies in charge of governance of service sector SME policy, for example, especially in the context of the described transitional economies.

\section{References}

[1] Aktan, B.; Bulut, C. Financial performance impacts of Corporate entrepreneurship in emerging markets: A case of
Turkey. // European Journal of Economics, Finance and Administrative Sciences. 12, (2008), pp. 69-79.

[2] Allen, N. J.; Meyer, J. P. The measurement and antecedents of affective, continuance, and normative commitment to the organization. // Journal of Occupational Psychology. 63, (1990), pp. 1-18. DOI: 10.1111/j.2044-8325.1990.tb00506.x

[3] Anderson, A. R.; Dodd, S. D.; Jack, S. Network practices and entrepreneurial growth. // Scandinavian Journal of Management. 26, 2(2010), pp. 121-133. DOI: 10.1016/j.scaman.2010.01.005

[4] Anderson, J. C.; Narus, J. A. A model of distributor firm and manufacturer firm working partnerships. // The Journal of Marketing. 54, 1(1990), pp. 42-58. DOl: 10.2307/1252172

[5] Asch, D.; Salaman, G. The challenge of change. // European Business Journal. 14, 3(2002), pp. 133-143.

[6] Awang, A.; Ahmad, Z. A.; Asghar, A. R. S; Subari, K. A.; Kassim, S. A. Firm entrepreneurial orientation and knowledge/networking of agro-based enterprises in Malaysia: The role of technology and strategy. // African Journal of Business Management. 5, 22(2011), pp. 96849704.

[7] Birkinshaw, J. Entrepreneurship in multinational corporations: The characteristics of subsidiary initiatives. // Strategic Management Journal. 18, (1997), pp. 207-229. DOI: $\quad$ 10.1002/(SICI)1097-0266(199703)18:3<207::AIDSMJ864>3.0.C0;2-Q

[8] Borgatti, S. P.; Halgin, D. S. On network theory. // Organization Science. 22, 5(2011), pp. 1168-1181. DOI: 10.1287/orsc. 1100.0641

[9] Borgatti, S. P.; Foster, P.C. The Network Paradigm in Organizational Research: A Review and Typology. // Journal of Management. 29, 6(2003), pp. 991-1013. DOl: 10.1016/S0149-2063(03)00087-4

[10] Boyd, B.; Dess, G. G.; Rasheed, A. Divergence between archival and perceptual measures of the environment: causes and consequences. // Academy of Management Review, 18, (1993), pp. 204-226.

[11] Chang, M.T.; Harwood, R.J. The Use of Strategic Networks to Enhance Global Competitiveness in the Hong Kong Clothing Manufacturing Industry. // Journal of the Textile Institute. $92, \quad 1(2001), \quad$ pp. 76-83. DOI: 10.1080/00405000108659598

[12] Cook, K. S.; Levi, M.; Hardin, R. Whom Can we Trust? How Groups, Networks and Institutions Make Trust Possible. Russell Sage Foundation Publications. New York, 2009

[13] Covin, J. G.; Slevin, D. P. A conceptual model of entrepreneurship as firm behavior. // Entrepreneurship Theory and Practice. (1991), pp. 7-25.

[14] Covin, J. G.; Slevin, D. P. Strategic management of small firms in hostile and benign environments. // Strategic Management Journal. 10, (1989), pp. 75-87. DOl: 10.1002/smj.4250100107

[15] Desarbo, W. S.; Di Benedetto, C. A.; Song, M.; Sinha, I. Revisiting the Miles and Snow strategic framework: Uncovering interrelationships between strategic types, capabilities, environmental uncertainty, and firm performance. // Strategic Management Journal. 26(2005), pp. 47-74. DOI: $10.1002 / \mathrm{smj} .431$

[16] Dess, G. G.; Lumpkin, G. T.; Covin, J. G. Entrepreneurial strategy making and firm performance: Test of contingency and configurational models. // Strategic Management Journal. 18, 9(1997), pp. 677-695. DOI: 10.1002/(SICI)10970266(199710)18:9<677::AID-SMJ905>3.0.CO;2-Q

[17] Donckels, R.; Lambrecht, J. Networks and Small Business Growth: An Explanatory Model. // Small Business Economics. 7, (1995), pp. 273-289. DOI: 10.1007/BF01108617

[18] Duchesneau, D. A.; Gartner, W. B. A profile of new venture success and failure in an emerging industry. // 
Journal of Business Venturing. 5, 5(1990), pp. 297-312. DOI: 10.1016/0883-9026(90)90007-G

[19] Eriksson, P. E.; Pesamaa, O. Modelling procurement effects on cooperation. // Construction management and economics. 25(2007), pp. 893-901. DOI: $10.1080 / 01446190701468844$

[20] Garbarino, E.; Johnson, M. S. The Different Roles of Satisfaction, Trust, and Commitment in Customer Relationships. // The Journal of Marketing. 63, 2(1999), pp. 70-87. DOI: $10.2307 / 1251946$

[21] Greenley, G. E.; Foxall, G. R. External moderation of associations among stakeholder orientations and company performance. London: Thompson Business Press, 1999.

[22] Gulati, R.; Nohria, N.; Zaheer, A. Strategic Network. // Strategic Management Journal. 21, 3(2000), pp. 203-215. DOI: SMJ102>3.0.CO;2-K

[23] Gupta, A. K.; Govindarajan, V. Business unit strategy, managerial characteristics, and business unit effectiveness at strategy implementation. // Academy of Management Journal. 27, (1984), pp. 25-41. DOI: 10.2307/255955

[24] Hansen, H.; Samuelsen, B. M.; Silseth, P. R. Customer percived value in B-t-B service relationships: Investigating the importance of corporate reputation. // Industrial Marketing Management. 37, 2(2008), pp. 206-217. DOl: 10.1016/j.indmarman.2006.09.001

[25] Human, S. E.; Provan, K. G. An Emergent Theory of Structure and Outcomes in Small-Firm Strategic Manufacturing Networks. // The Academy of Management Journal. 40, 2(1997), pp. 368-403. DOI: 10.2307/256887

[26] Kline, R. B. Principles and Practice of Structural Equation Modeling, 2E, The Guilford Press, NY, 2005.

[27] Krause, K.; Hartley, R.; James, R.; McInnis, C. The First Year Experience in Australian Universities: Findings from a decade of national studies. DEST, Canberra, 2005.

[28] Kreiser, P. M.; Marino, L. D.; Weaver, K. M. Assessing the Psychometric Properties of the EO Scale: A Multi-Country Analysis. // Entrepreneurship Theory and Practice. 26, 4(2002), pp. 71-94.

[29] Kusumawardhani, A.; McCarthy, G.; Perera, N. Framework of entrepreneurial orientation and networking: a study of SMEs performance in a developing country. // Proceedings of the Australian and New Zealand Academy of Management Conference, Adelaide, 2009, pp. 1-16.

[30] Larsson, E.; Hedelin, L.; Garling, T. Influence of expert advice on expansion goals of small businesses in rural Sweden. // Journal of Small Business Management. 41, 2(2003), pp. 205-212. DOI: 10.1111/1540-627X.00076

[31] Lerner, M.; Brush, C.; Hisrich, R. Israeli women entrepreneurs: an examination of factors affecting performance. // Journal of Business Venturing. 12, 4(1997), pp. 315-339. DOI: 10.1016/S0883-9026(96)00061-4

[32] Lin, C. Y.; Zhang, J. Changing structures of SME networks: lessons from the publishing industry in Taiwan. //, Long Range Planning, 38(2005), pp. 145-162. DOI: 10.1016/j.Irp.2005.02.007

[33] Lumpkin, G. T.; Cogliser, C. C.; Schneider, D. R. Understanding and measuring autonomy: An EO perspective. // Entrepreneurship theory and practice. 33, 1(2009), pp. 47-69. DOI: 10.1111/j.1540-6520.2008.00280.x

[34] Lumpkin, G. T.; Dess, G. G. Clarifying the EO construct and linking it to performance. // Academy of Management Review. 21, (1996), pp. 135-172.

[35] Lumpkin, G. T.; Dess, G. G. Linking two dimensions of EO to firm performance: The moderating role of environment and industry life cycle. // Journal of Business Venturing. 16, (2001), pp. 429-451. DOI: 10.1016/S0883-9026(00)00048-3

[36] Lyon, D. W.; Lumpkin, G. T.; Dess, G. G. Enhancing EO research: operationalizing and measuring a key strategic decision making process. // Journal of Management. 26, (2000), pp. 1055-1085. DOI: 10.1177/014920630002600503

[37] Malhotra, N. M. Marketing research: an applied orientation. Pearson, NJ, 2010. DOI: 10.1108/S1548-6435(2010)6

[38] Miller, D. The correlates of entrepreneurship in three types of firms. // Management Science. 29, 7(1983), pp. 770-791. DOI: 10.1287/mnsc.29.7.770

[39] Miller, D.; Friesen, P. Innovation in conservative and entrepreneurial firms: Two models of strategic momentum. // Strategic Management Journal. 3, 1(1982), pp. 1-25. DOI: 10.1002/smj.4250030102

[40] Miller, K. D.; Bromiley, P. Strategic Risk and Corporate Performance: An Analysis of Alternative Risk Measures. // Academy of Management Journal. 33, (1990), pp. 756-779. DOI: $10.2307 / 256289$

[41] Naman, J. L.; Slevin, D. P. Entrepreneurship and the concept of fit: A model and empirical tests. // Strategic Management Journal. 14, (1993), pp. 137-153. DOl: 10.1002/smj.4250140205

[42] Robson, P. J.; Bennett, R. J. SME growth: The relationship with business advice and external collaboration. // Small Business Economics. 15, 3(2000), pp. 193-208. DOI: 10.1023/A:1008129012953

[43] Roger, B. M. Coping with complexity and turbulence-an entrepreneurial solution. // Journal of Enterprising Culture. 14, 4(2006), pp. 241-266. DOI: 10.1142/S0218495806000155

[44] Saleh, A. S.; Ndubisi, N. O. An Evaluation of SME Development in Malaysia. // International Review of Business Research Papers. 2, 1(2006), pp. 1-14.

[45] Sivadas, E.; Dwyer, F.R. An examination of organizational factors influencing new product success in internal and alliance based processes. // Journal of Marketing, 64(2000), pp. 31-49. DOl: 10.1509/jmkg.64.1.31.17985

[46] Stopford. J. Should strategy makers become dream weavers. // Harvard Business Review. 79, 1(2001), pp. 165169.

[47] Street, C. T.; Cameron, A. F. External Relationships and the Small Business: A Review of Small Business Alliance and Network Research. // Journal of Small Business Management. 45, 2(2007), pp. 239-266. DOI: 10.1111/j.1540627X.2007.00211.X

[48] Ward, S.; Lewandowska, A. Shelter in the storm: marketing strategy as moderated by the hostile environment. // Marketing Intelligence and Planning. 23, 7(2005), pp. 670687. DOI: $10.1108 / 02634500510630203$

[49] Wiklund, J. The sustainability of the EO - performance relationship. // Entrepreneurship Theory and Practice. 24, (1999), pp. 37-48.

[50] Wiklund, J.; Shepherd, D. EO and small business performance: A configurational approach. // Journal of Business Venturing. 20, (2005), pp. 71-91. DOI: 10.1016/j.jbusvent.2004.01.001

[51] Yeoh, P. Entrepreneurship and export performance: a proposed conceptual model. // Advances in International Marketing, 6, (1994), pp. 43-68.

[52] Zahra, S. A. Predictors and financial outcomes of corporate entrepreneurship: An exploratory study. // Journal of Business Venturing. 6, (1991), pp. 259-285. DOI: 10.1016/0883-9026(91)90019-A

[53] Zahra, S. A.; Covin, J. Contextual influence on the corporate entrepreneurship-performance relationship: A longitudinal analysis. // Journal of Business Venturing. 10, (1995), pp. 43-58. DOI: 10.1016/0883-9026(94)00004-E

[54] Zahra, S. A.; Covin, J. G. Business strategy, technology policy, and firm performance. // Strategic Management Journal. 14, 6(1993), pp. 451-478. DOI: 10.1002/smj.4250140605

[55] Zhao, L.; Aram, J. D. Networking and growth of young technology-intensive ventures in China. // Journal of 
Business Venturing. 10, 5(1995), pp. 349-370. DOl:

10.1016/0883-9026(95)00039-B

\section{Authors' addresses}

Bojan Morić Milovanović, Assistant Professor, PhD

DIU Libertas International University

Trg J. F. Kennedya 6b, 10000 Zagreb, Croatia

E-mail: bmoric@libertas.hr

Dinko Primorac, Assistant Professor, PhD

University North

Trg dr. Žarka Dolinara 1, 48000 Koprivnica, Croatia

E-mail: dinko.primorac@unin.hr

Goran Kozina, Professor, PhD

University North

Trg dr. Žarka Dolinara 1, 48000 Koprivnica, Croatia

E-mail: goran.kozina@unin.hr 